\title{
Characterization of extended-spectrum beta-lactamase-producing fecal Escherichia coli isolates in laying hens
}

\author{
Faruk PEHLIVANOĞLU ${ }^{1}$, Hülya TÜRÜTOĞLU' ${ }^{1}$, Dilek ÖZTÜRK ${ }^{1}$, Hakan YARDIMCI² \\ ${ }^{1}$ Mehmet Akif Ersoy University, Faculty of Veterinary Medicine, Department of Microbiology, Burdur; ${ }^{2}$ Ankara University, Faculty \\ of Veterinary Medicine, Department of Microbiology, Ankara, Turkey.
}

\begin{abstract}
Summary: The purposes of the present study were to determine whether healthy laying hens in Burdur province of Turkey carried extended-spectrum beta-lactamase (ESBL)- producing Escherichia coli in their intestinal flora and to further characterize the $E$. coli isolates and ESBL genes. A total of 200 fecal samples from three laying hen farms were cultured in Brilliance E. coli / coliform Selective Agar supplemented with cefotaxime or ceftazidime. ESBL-producing E. coli isolates determined by phenotypic tests were screened by Polymerase Chain Reaction (PCR) for ESBL genes, and ESBL genes were sequenced. Phylogenetic analysis of the E. coli isolates were performed by PCR. ESBL-producing E. coli were isolated from $12(6.0 \%)$ laying hen fecal samples by phenotypic tests.

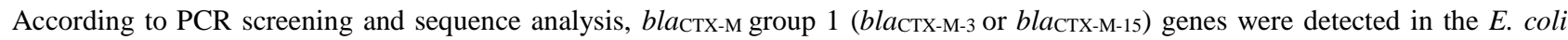
isolates. Phylogenetic analysis of the E. coli isolates showed that group D was the predominant group (58.3\%) and none of the isolates belonged to group B2. Consequently, present study reports the first characterisation of CTX-M-3 and CTX-M-15 type ESBL-producing E. coli isolates on laying hen production from Turkey.
\end{abstract}

Keywords: CTX-M-3, CTX-M-15, Escherichia coli, laying hens, phylogenetic analysis.

\section{Yumurtacı tavuklarda genişlemiş spektrumlu beta laktamaz üreten dışkı kökenli Escherichia coli izolatlarının karakterizasyonu}

Özet: $\mathrm{Bu}$ çalışmada, Burdur ilindeki yumurtacı tavukların bağırsak mikroflorasında genişlemiş spektrumlu beta laktamaz (GSBL) üreten Escherichia coli varlığının ortaya çıkarılması ve izole edilen E. coli izolatlarının ve taşıdıkları GSBL genlerinin karakterize edilmesi amaçlandı. Toplam üç tavuk çiftliğinden alınan 200 dışkı örneği, içerisine sefotaksim ve seftazidim ilave edilmiş Brilliance E. coli / koliform Selektif Agara ekildi. Fenotipik testlerle belirlenen GSBL üreten E. coli izolatları GSBL genleri yönünden Polimeraz Zincir Reaksiyonu (PZR) ile tarandı ve GSBL genlerinin sekans analizi yapıldı. İzolatların filogenetik analizi PZR ile gerçekleştirildi. Fenotipik testler ile GSBL üreten $E$. coli $12(\% 6.0)$ adet dışk1 örneğinde belirlendi. PZR ve sekans analizine göre, $E$. coli izolatlarında bla стХ-м grup 1 genleri (bla стХ-м-3 ve bla СтХ-м-15) belirlendi. İzolatların filogenetik analizi grup D'nin en yaygın olduğunu (\%58.3) ve izolatların hiç birinin B2 grubundan olmadığını gösterdi. Sonuç olarak, bu çalışma Türkiye'de yumurta tavuklarında CTX-M-3 and CTX-M-15 type GSBL üreten E. coli izolatlarını tanımlayan ilk rapordur.

Anahtar sözcükler: CTX-M-3, CTX-M-15, Escherichia coli, filogenetik analiz, yumurtacı tavuk.

\section{Introduction}

Beta-lactam antibiotics are among the most useful treatment options for bacterial infections of human and animals. The most common bacterial resistance to betalactam antibiotics can be achieved by the production of beta-lactamase enzymes by the resistant bacteria that hydrolyse the beta-lactam ring (amid bond) of the antibiotics (11). A group of beta-lactamases known as extended-spectrum beta-lactamases (ESBLs) provide resistance to Gram-negative bacteria against several antibiotics including penicillins, $1^{\text {st }}-4^{\text {th }}$ generation cephalosporins and monobactams (e.g., aztreonam). ESBLs are not active against carbapenems (e.g., imipenem, meropenem and ertapenem) or cephamycins (e.g., cefoxitin). Beta-lactamase inhibitors such as clavulanic acid (CLA) and tazobactam, inhibit the ESBLs and this characteristic is used in their laboratory detection and confirmation (19). ESBLs are plasmid mediated and TEM, SHV and CTX-M groups are the most prevalent ESBLs in Enterobacteriaceae (19). ESBLs of TEM and SHV groups originate from TEM-1/TEM-2 and SHV-1 beta-lactamase genes (bla $a_{\mathrm{TEM}-1} / b l a_{\mathrm{TEM}-2}$ and $\left.b l a_{\mathrm{SHV}-1}\right)$, respectively, via mutations (19). On the other hand, CTX$\mathrm{M}$ beta-lactamase genes $\left(\right.$ bla $\left.a_{\mathrm{CTX}-\mathrm{M}}\right)$ have been captured from the chromosome of Kluyvera spp. by conjugation (20). Based on aminoacid sequence similarities CTX-M type ESBL variants are divided into 5 groups, called group 1, 2, 8, 9 and 25 (19). 
The presence of ESBL-producing Escherichia coli isolates and ESBL types that they produced have been investigated in poultry productions from various parts of the world $(4,16,17,25)$. However, in Turkey, little is known about avian ESBL-producing $E$. coli. In the only study conducted with laying hen farms in Turkey (Marmara region), phenotypic detection of ESBLproducing E. coli isolates and PCR detection of ESBL genes were performed but ESBL variants were not revealed by sequencing in that study (3). Until now there is only one Turkish study conducted in which both the presence and types of ESBLs in healthy chickens were investigated in a small-scale local study in Turkey (23) but it covered only the broiler chickens. Such information for laying hen productions in Turkey is necessary to better understand the epidemiology of ESBLs in poultry and to develop control strategies. Therefore, the present study was carried out to show the emergence of ESBLproducing E. coli isolates in healthy laying hens in Burdur province of Turkey and to further characterize the E. coli isolates and ESBL genes.

\section{Materials and Methods}

Sample collection: The study population included three laying hen farms which constitute all chicken farms in Burdur province located in southwest of Turkey. Two hundreds fecal samples (50 samples from each of farm A and $\mathrm{B}$, and 100 samples from farm C) were collected from cages by using sterile swabs provided that only one fecal sample from a cage. The fecal samples were placed in sterile screw-top vials, transported to the laboratory on ice and held at $4^{\circ} \mathrm{C}$ until processing within $24 \mathrm{~h}$.

Selective isolation and phenotypic confirmation of ESBL-producing E. coli isolates: Firstly, a $10 \%$ suspension of a fecal sample in buffered peptone water ( $\mathrm{Lab} \mathrm{M}, \mathrm{UK}$ ) was prepared and incubated at $37^{\circ} \mathrm{C}$ for 24 $\mathrm{h}$ under aerobic conditions. Then, $50 \mu \mathrm{l}$ was evenly spread onto Brilliance E. coli/coliform Selective Agar (Oxoid, UK) supplemented with cefotaxime (CTX, $2 \mu \mathrm{g} / \mathrm{ml}$ ) (Sigma Aldrich, Germany) or ceftazidime (CAZ, $2 \mu \mathrm{g} / \mathrm{ml}$ ) (Sigma Aldrich, Germany) and the plates were incubated at $37^{\circ} \mathrm{C}$ for $24 \mathrm{~h}$ under aerobic conditions.

One colony from each plate per positive sample was selected randomly and $E$. coli identification was performed based on conventional methods (Gram staining, acid and gas from glucose, catalase test, citrate utilization, decarboxylation of lysine, hydrogen sulphide production, indole production, methyl red-voges proskauer test, orthonitrophenyl-beta-D-galactopyranoside activity, oxidase test and urease production) (26). DNAs of E. coli isolates were extracted by using a genomic DNA purification kit (Thermo Fisher Scientific Inc.) and genetic confirmation was carried out by Polymerase Chain Reaction (PCR) amplification targeting E. coli 16S rRNA gene (24).
ESBL production by $E$. coli isolates was confirmed by the combined disc method as recommended by the CLSI (8).

Antibiotic susceptibility testing: Susceptibility of ESBL-producing $E$. coli isolates to 8 beta-lactam antibiotics were investigated by the agar disc diffusion test on MHA (Oxoid, UK) according to the CLSI protocols (8). The list of the antibiotic discs (Oxoid, UK) tested were as follows: ampicillin (AMP, $10 \mu \mathrm{g}$ ), aztreonam (ATM, 30 $\mu \mathrm{g}$ ), cefepime (FEP, $30 \mu \mathrm{g}$ ), cefpodoxime (CPD, $10 \mu \mathrm{g}$ ), ceftriaxone (CRO, $30 \mu \mathrm{g})$, cefuroxime (CXM, $30 \mu \mathrm{g})$, cephalothin (CEF, $30 \mu \mathrm{g}$ ), and imipenem (IPM, $10 \mu \mathrm{g}$ ).

To explore if the isolates had co-resistance to other classes of antibiotics, they were additionally subjected to susceptibility testing against the following antibiotics (Oxoid, UK) by agar disc diffusion test on MHA (Oxoid, UK) as recommended by CLSI (8): chloramphenicol (CHL), ciprofloxacin (CIP, $5 \mu \mathrm{g}$ ), enrofloxacin (ENR, 5 $\mu \mathrm{g}$ ), florfenicol (FFC, $30 \mu \mathrm{g}$ ), gentamicin (GEN, $10 \mu \mathrm{g}$ ), kanamycin (KAN, $30 \mu \mathrm{g}$ ), nalidixic acid (NAL, $30 \mu \mathrm{g}$ ), streptomycin (STR, $10 \mu \mathrm{g})$, sulfamethoxazoletrimethoprim (SXT, $25 \mu \mathrm{g}$ ) and tetracycline (TET, $30 \mu \mathrm{g}$ ).

Antibiotic susceptibility test results were evaluated according to inhibition zone diameters recommended by CLSI $(6,7,8)$. The isolates were classified as resistant or susceptible. The E. coli isolates with the same antibiotic susceptibility phenotype from both media (supplemented with CTX or CAZ) per positive fecal sample were considered as the same isolate. In the present study, multidrug-resistance was described as resistance to more than 3 classes of antibiotics except beta-lactams.

PCR and sequencing: PCR screening of bla $a_{\mathrm{TEM}}(1$, 13), bla $_{\mathrm{SHV}}(13,22)$ and bla $a_{\mathrm{CTX}-\mathrm{M}}$ type $(9,13,15,21)$ genes of phenotypically confirmed ESBL-producing E. coli isolates was carried out as described previously with slight modifications in the cycling conditions. The cycling conditions for detection of $b l a_{\text {TEM }}$ gene were as follows: initial denaturation at $94^{\circ} \mathrm{C}$ for $5 \mathrm{~min}$, followed by 35 cycles of $1 \mathrm{~min}$ at $94^{\circ} \mathrm{C}, 1 \mathrm{~min}$ at $48^{\circ} \mathrm{C}$ and $1 \mathrm{~min}$ at $72^{\circ} \mathrm{C}$, with a final extension step at $72^{\circ} \mathrm{C}$ for $10 \mathrm{~min}$. The cycling conditions for bla $a_{\mathrm{SHV}}$ gene detection were initial denaturation at $94^{\circ} \mathrm{C}$ for $5 \mathrm{~min}, 35$ cycles of $94^{\circ} \mathrm{C}$ for 30 sec, $58^{\circ} \mathrm{C}$ for $30 \mathrm{sec}$ and $72{ }^{\circ} \mathrm{C}$ for $1 \mathrm{~min}$, and a final extension at $72^{\circ} \mathrm{C}$ for $7 \mathrm{~min}$. The cycling conditions for bla $a_{\text {СтХ-м }}$ gene (universal) consisted of initial denaturation at $94^{\circ} \mathrm{C}$ for $5 \mathrm{~min}, 35$ cycles of $94^{\circ} \mathrm{C}$ for $30 \mathrm{sec}, 54^{\circ} \mathrm{C}$ for $30 \mathrm{sec}$ and $72^{\circ} \mathrm{C}$ for $1 \mathrm{~min}$, and a final extention step at $72^{\circ} \mathrm{C}$ for $7 \mathrm{~min}$. Finally, detection of $b l a_{\mathrm{CTX}-\mathrm{M}}$ group 1,2 , 9 and 8/25 genes were performed with the following PCR cycling conditions: initial denaturation at $94^{\circ} \mathrm{C}$ for $5 \mathrm{~min}$, 35 amplification cycles of $94^{\circ} \mathrm{C}$ for $1 \mathrm{~min}, 55^{\circ} \mathrm{C}$ for $1 \mathrm{~min}$ and $72^{\circ} \mathrm{C}$ for $1 \mathrm{~min}$, and a final extension step at $72^{\circ} \mathrm{C}$ for 7 min. E. coli ATCC 35218 (bla TEM-1 ) and Klebsiella pneumoniae ATCC 700603 (bla $a_{\mathrm{SHV}-18}$ ) were used as 
positive control strains for bla $a_{\mathrm{TEM}}$ and bla $a_{\mathrm{SHV}}$ genes, respectively. E. coli NCTC 13461, E. coli NCTC 13462, E. coli NCTC 13463, Enterobacter cloacae NCTC 13464 and K. pneumoniae NCTC 13465 were used as positive

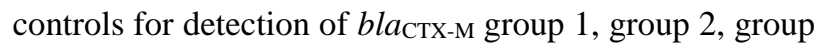
8, group 9 and group 25 genes, respectively. E. coli ATCC 25922 was included in all PCRs as a negative control.

PCR products obtained from ESBL-producing $E$. coli isolates were subjected to DNA sequencing. DNA sequencing was carried out by the Refgen Genetical Research and Biotechnology Company (Gölbaşı-Ankara, Turkey). Sequencing was performed with both forward and reverse primers which were used in the PCR. To determine the variants of beta-lactamase genes, the sequences were compared with NCBI GenBank sequences using BLAST. Finally, nucleotid sequences of selected ESBL genes were submitted to NCBI GenBank.

Phylogenetic analysis: A triplex PCR protocol was used to reveal phylogenetic groups (A, B1, B2 and D) of all $E$. coli isolates in the present study, as described by Clermont et al. (5) with the modified PCR conditions (14). E. coli ATCC 25922 was used as positive control strain in the triplex PCR. For better discrimination of the strains, phylogenetic subgroups (A: $\mathrm{A}_{0}$ and $\mathrm{A}_{1} ; \mathrm{B} 2$ : $\mathrm{B} 2_{2}$ and $\mathrm{B} 2_{3}$; $D: D_{1}$ and $D_{2}$ ) were also investigated as described by Escobar-Páramo et al. (10).

\section{Results}

After the enrichment step and inoculation on Brilliance $E$. coli/coliform selective agar with CTX (2 $\mu \mathrm{g} / \mathrm{ml})$ or CAZ $(2 \mu \mathrm{g} / \mathrm{ml}), E$ coli colonies were detected on both cultures of 27 fecal samples. Biochemical identification and PCR for 16S rRNA gene confirmed all of them as E. coli (Figure 1). Further characterization using the combined disc method confirmed $12 \mathrm{E}$. coli isolates $(12 / 200,6 \%)$ from two farms, farm B and C, as ESBL producers. Within farm isolation rate was $16 \%$ (8/50) for farm B and 4\% (4/100) for farm C.

In antibiotic susceptibility testing against beta lactams, all ESBL producing E. coli isolates were found to be resistant to AMP, ATM, CTX, CPD, CAZ, CRO, CXM, CEF, susceptible to FOX and IPM. Five (41.7\%) E. coli isolates were resistant to FEP. According to antibiotic susceptibility testing against other classes of antibiotics, all isolates were susceptible to GEN, FFC, and CHL. Resistance ratios for KAN, STR, CIP, ENR, NAL, TET, and SXT were $25 \%, 8.3 \%, 25 \%, 25 \%, 75 \%, 58.3 \%$ and $8.3 \%$, respectively. One ESBL-producing E. coli isolate (CTX-M-15 producer) (1/12, 8.3\%) from farm C was determined as multidrug-resistant (Table 1).

PCR screening for the $b l a_{\mathrm{TEM}}, b l a_{\mathrm{SHV}}$ and $b l a_{\mathrm{CTX}-\mathrm{M}}$ genes in phenotypically-confirmed ESBL-producing $E$. coli isolates indicated that all isolates $(12 / 12,100 \%)$

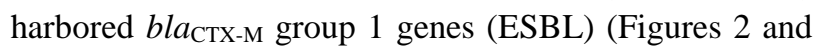
3 ) and 2 of which $(2 / 12,16.7 \%)$ possessed also bla $a_{\text {TEM }}$ gene (Figure 4). bla $a_{\text {SHV }}$ gene was not detected in the isolates (Table 1).

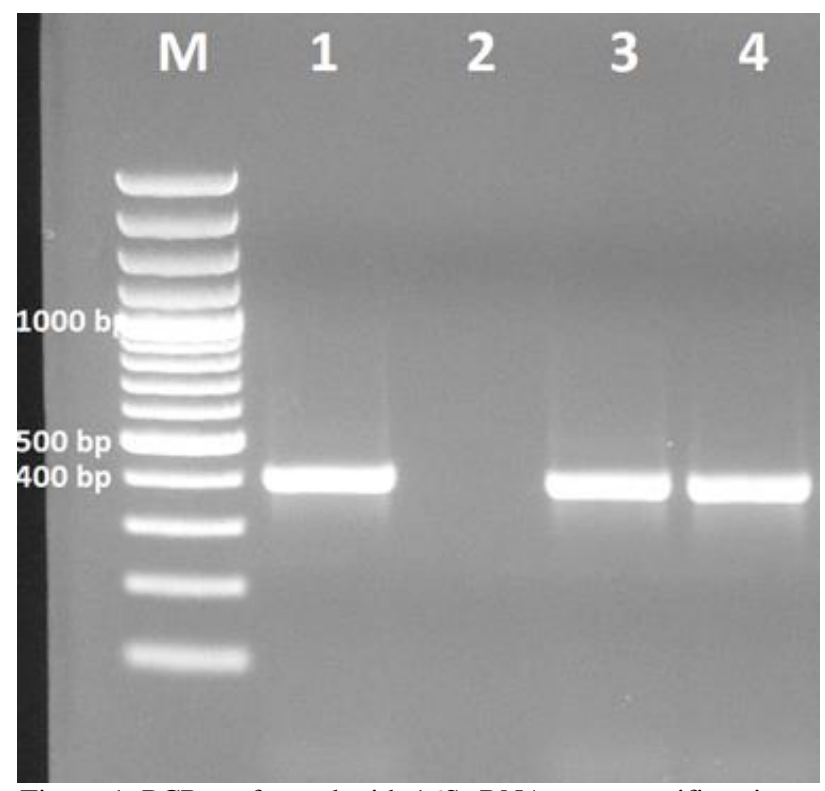

Figure 1. PCR performed with 16S rRNA gene specific primers (401 bp). M: Marker (100 bp), 1: Positive control (E. coli ATCC 25922), 2: Negative control (PCR mixture without template DNA), 3 and 4: E. coli isolated from laying hens (isolates: F73 and F92).

Şekil 1. 16S rRNA geni için spesifik primerlerle (401 bp) yapılan PZR. M: Marker (100 bp), 1: Pozitif kontrol (E. coli ATCC 25922), 2: Negatif kontrol (kalıp DNAsız PZR karışımı), 3 ve 4: Yumurta tavuklarından izole edilen E. coli (izolatlar: F73 ve F92).

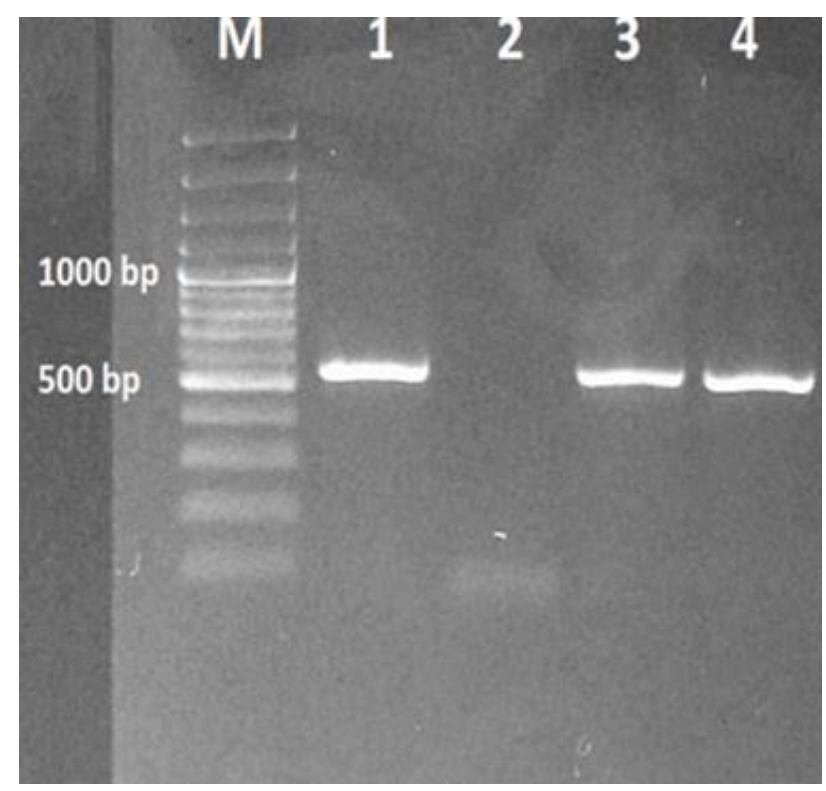

Figure 2. PCR performed with CTX-M gene universal primers (543 bp). M: Marker (100 bp), 1: Positive control (E. coli NCTC 13461), 2: Negative kontrol (PCR mixture without template DNA), 3 ve 4: CTX-M gene positive $E$. coli isolated from laying hens (isolates: F73 and F92).

Şekil 2. CTX-M geni universal primerleri (543 bp) ile yapılan PZR. M: Marker (100 bp), 1: Pozitif kontrol (E. coli NCTC 13461), 2: Negatif kontrol (kalıp DNAsız PZR karışımı), 3 ve 4: Yumurta tavuklarından izole edilen CTX-M geni taşıyan E. coli (izolatlar: F73 ve F92). 
Table 1. Distribution of ESBL-producing E. coli isolates $(\mathrm{n}=12)$ according to phylogenetic group and antibiotic resistance profiles. Tablo 1. GSBL üreten $E$. coli izolatlarının (n=12) filogenetik grup ve antibiyotik direnç profillerine göre dağılımı.

\begin{tabular}{llllll}
\hline Herd & $\begin{array}{l}\text { Fecal sample } \\
(\mathrm{n})\end{array}$ & $\begin{array}{l}\text { E. coli isolated } \\
(\mathrm{n})(\%)\end{array}$ & Phylogenetic type & ESBL type & Antibiotic susceptibility profile \\
\hline \multirow{2}{*}{$\mathrm{B}$} & \multirow{2}{*}{50} & $8(16.0)$ & $\mathrm{B} 1(\mathrm{n}=2)$ & CTX-M-3 & $-(\mathrm{n}=2)$ \\
\cline { 3 - 5 } & & D2 $(\mathrm{n}=6)$ & CTX-M-15 & $\begin{array}{l}\text { TET, NAL }(\mathrm{n}=5) \\
\text { TET }(\mathrm{n}=1)\end{array}$ \\
\hline \multirow{2}{*}{$\mathrm{C}$} & \multirow{2}{*}{100} & $4(4.0)$ & $\mathrm{B} 1(\mathrm{n}=3)$ & CTX-M-15 & KAN, NAL, CIP, ENR (n=3) \\
\cline { 3 - 5 } & & D1 $(\mathrm{n}=1)$ & CTX-M-15 & ${ }^{\mathrm{a}}$ STR, SXT, NAL, TET $(\mathrm{n}=1)$ \\
\hline
\end{tabular}

n: Number, ${ }^{\text {a: }}$ Multidrug-resistant $E$. coli isolate.

n: Sayı, a: Çoklu antibiyotik direnci gösteren E. coli izolatı.

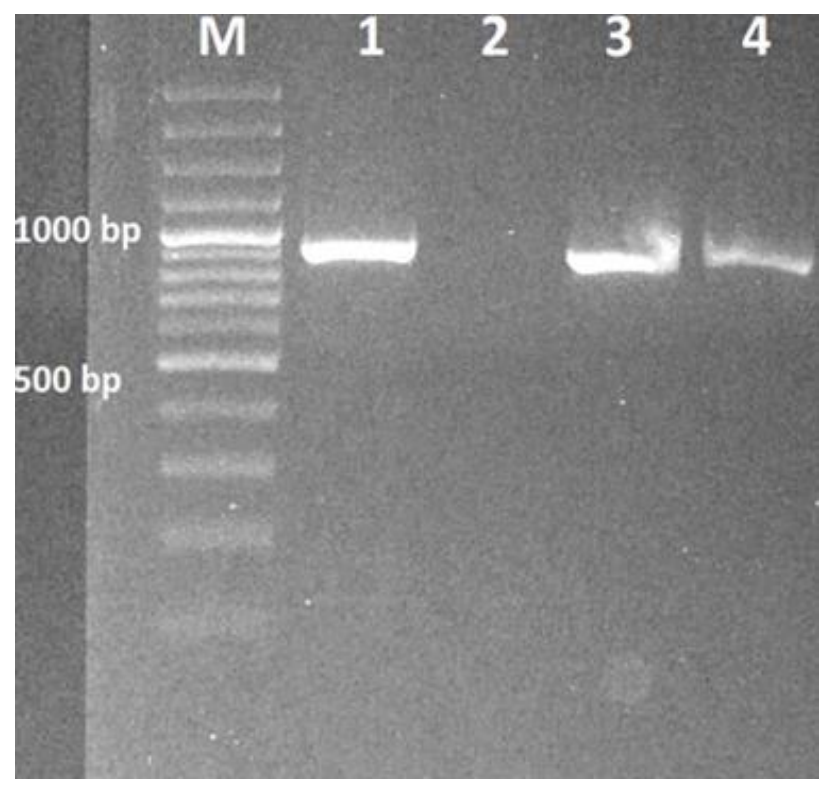

Figure 3. PCR performed with CTX-M gene group 1 primers (891 bp). M: Marker (100 bp), 1: Positive control (E. coli NCTC 13461), 2: Negative control (PCR mixture without template DNA), 3 ve 4: CTX-M gene (group 1) positive E. coli isolated from laying hens (isolates: F73 and F92).

Şekil 3. CTX-M geni grup 1 primerleri (891 bp) ile yapılan PZR. M: Marker (100 bp), 1: Pozitif kontrol (E. coli NCTC 13461), 2: Negatif kontrol (kalıp DNAsız PZR karışımı), 3 ve 4: Yumurta tavuklarından izole edilen CTX-M geni (grup 1) taşıyan E. coli (izolatlar: F73 ve F92).

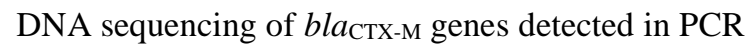
screening indicated CTX-M-15 as predominant ESBL $(10 / 12,83.3 \%)$ and CTX-M-3 as less frequent type (2/12, $16.7 \%$ ). Additionally, DNA sequencing of 2 bla $a_{\text {TEM }}$ gene PCR products showed that they are TEM-1 beta-lactamase which is not an ESBL (Table 1). Assigned accession numbers for bla $a_{\mathrm{CTX}-\mathrm{M}-3}\left(E\right.$. coli isolate: F73) and bla $a_{\mathrm{CTX}-\mathrm{M}-}$ 15 gene ( $E$. coli isolate: F92) nucleotid sequence data submitted in Genbank are KP303591 and KX274458, respectively.

According to phylogenetic typing of $E$. coli isolates, isolates from farm B belonged to $B 1(n=2)$ and $D_{2}(n=6)$ phylogenetic groups and the isolates from farm $\mathrm{C}$ belonged to $D_{1}(n=1)$ and $B 1(n=3)$ phylogenetic groups (Table 1).

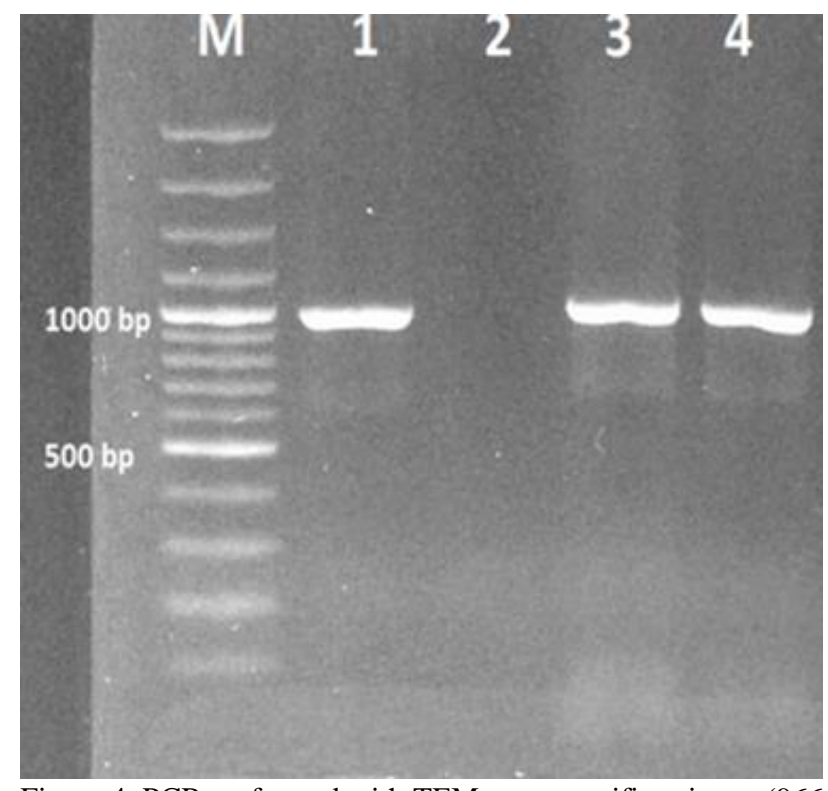

Figure 4. PCR performed with TEM gene specific primers (966 bp). M: Marker (100 bp), 1: Positive control (E. coli ATCC 35218), 2: Negative control (PCR mixture without template DNA), 3 ve 4: TEM gene positive $E$. coli isolated from laying hens (isolates: F151 and F196).

Şekil 4. TEM geni için spesifik primerlerle (966 bp) yapılan PZR. M: Marker (100 bp), 1: Pozitif kontrol (E. coli ATCC 35218), 2: Negatif kontrol (kalıp DNAsız PZR karışımı), 3 ve 4: Yumurta tavuklarından izole edilen TEM geni taşıyan E. coli (izolatlar: F151 ve F196).

\section{Discussion and Conclusion}

Avian E. coli isolates which are ESBL producers have been reported in poultry in various parts of the world $(4,16,17,25)$. However, to date, majority of the studies focused on broiler chickens and large-scale studies on the presence and extent of ESBL-producing $E$. coli isolates in laying hens are limited. Bortolaia et al. (4) reported E. coli isolates producing CTX-M group 1 (CTX-M-1/61), group 2 (CTX-M-2/20/44) and group 9 (CTX-M-14/17) betalactamases in layer flocks in Denmark. Wasyl et al. (25) isolated 3 CTX-M-1 and CTX-M-1+TEM-1b-producing E. coli from the laying chicken flocks in Poland. In the present study, isolation rate of ESBL-producing $E$. coli was determined as $6.0 \%$ in laying hens in Burdur province of Turkey and similarly CTX-M group-1 (CTX-M-3 and CTX-M-15 types) ESBLs were determined. Therefore, 
our study is the first report showing the existence of CTXM-3 and CTX-M-15 type ESBL-producing E. coli in laying hen farms from Turkey.

Plasmids bearing genes for ESBL production commonly carry other resistance determinants, such asaminoglycosides, phenicols, quinolones, sulfamethoxazole-trimethoprim and tetracycline, resulting in co-resistance to these antibiotics $(18,19)$. Similarly, in the present study we determined co-resistance to antibiotics mentioned above except phenicols (CHL and FFC), but the number of multidrug-resistant isolates were very low.

The increase in the prevalence of ESBL-producing E. coli is attributed to clonal spread of ESBL-producing strains and/or horizontal transfer of plasmids carrying ESBL genes (18). Studies showed that there was a dramatical increase in detection rates of CTX-M type ESBLs during the last decade globally (19). Similarly, bla $a_{\text {CTX-M }}$ gene was the only ESBL type detected in E. coli isolates in the present study; SHV and TEM type ESBLs were not detected. Hence, the present study also supportsthe increasing trend of the emergence and dissemination of CTX-M type ESBLs in animal production globally.

In the present study, the predominant ESBL was CTX-M group 1 (CTX-M-3 and -15) which is similar to the reports of human isolates in Turkey $(2,12)$. It is known that CTX-M (particularly CTX-M-15)-producing E. coli isolates cause both nosocomial and community-onset infections, such as bacteriemia, gastroenteritis and urinary tract infections, in human (19). Therefore, existence of CTX-M-15 type ESBL-producing E. coli isolates indicates the risk for people working in these farms and consuming egg from these farms. Additionaly, the data obtained in the present study show that there is similarity between human and poultry in the epidemiology of ESBL genes.

Phylogenetic analysis of $E$. coli isolates indicates that most of the commensal E. coli isolates belong to groups $\mathrm{A}$ and $\mathrm{B} 1$ and, virulent extraintestinal isolates belong to group B2 and lesser extent to group D (5). Phylogenetic analysis of all E. coli isolates in the present study showed that group $\mathrm{D}\left(\mathrm{D}_{1}\right.$ and $\left.\mathrm{D}_{2}\right)$ was the predominant group and was followed by group B1; none of the isolates belonged to group B2. Although none of the isolates in the present study were from B2 phylogenetic group, the isolates from group D should be considered as a potential risk for severe infections both in animals and human.

Additionally, the results of phylogenetic analysis indicate that few parent $E$. coli isolates carrying ESBL genes exist in the laying hen farms in Burdur province of Turkey. Therefore, prevention of dissemination of the low number parent $E$. coli isolates will be critical to keep the prevelance of ESBL-producing E. coli in low levels in the laying hen production in the region.

Consequently, we report the emergence of CTX-M3 and -15 type ESBL-producing $E$. coli isolates from 4 different phylogenetic groups in healthy laying hens in Burdur province of Turkey. Even if there is a low level of isolation in layers at present, it should be our major concern because of the possibility of transfer of ESBL genes between animal species as well as to humans by direct contact or by food chain. Thus, further researches including humans, food chain and environments of animals should be conducted to obtain information which will be helpful in order to develop control strategies in the field. Furthermore, investigations to reveal the relationship between antibiotic use and development of ESBL-producing E. coli isolates in poultry productions should be conducted.

\section{Acknowledgement}

The present study was funded by The Scientific and Technological Research Council of Turkey (TUBITAK, Project no: 1120820). Primers for phylogenetic analysis were obtained from Mehmet Akif Ersoy University, Scientific Research Projects Unit (Turkey) (Project no: 0158 KAYDEP-13).

\section{References}

1. Arpin C, Dubois V, Coulange L, et al. (2003): Extendedspectrum beta-lactamase-producing Enterobacteriaceae in community and private health care centers. Antimicrob Agents Chemother, 47, 3506-3514.

2. Azap OK, Arslan H, Serefhanoğlu K, et al. (2010): Risk factors for extended-spectrum beta-lactamase positivity in uropathogenic Escherichia coli isolated from communityacquired urinary tract infections. Clin Microbiol Infect, 16,147-151.

3. Basaran Kahraman B, Diren Siğirci B, Celik B, et al. (2016): Detection of extended-spectrum beta-lactamase and AmpC beta-lactamase producing Escherichia coli isolates from chickens. Kafkas Univ Vet Fak Derg, 22, 591-596.

4. Bortolaia V, Guardabassi L, Bisgaard M (2010): Escherichia coli producing CTX-M-1, -2, and -9 group beta-lactamases in organic chicken egg production. Antimicrob Agents Chemother, 54, 3527-3528.

5. Clermont O, Bonacorsi S, Bingen E (2000): Rapid and simple determination of the Escherichia coli phylogenetic group. Appl Environ Microbiol, 66, 4555-4558.

6. Clinical and Laboratory Standards Institute (CLSI) (2010): Performance standards for antimicrobial disk and dilution susceptibility tests for bacteria isolated from animals. $3^{r d}$ Ed. Approved standards M31-A3. Wayne, PA, USA.

7. Clinical and Laboratory Standards Institute (CLSI) (2013): Performance standards for antimicrobial disk and dilution susceptibility tests for bacteria isolated from animals. $2^{\text {nd }}$ Informational supplement VET01-S2. Wayne, PA, USA. 
8. Clinical and Laboratory Standards Institute (CLSI) (2015): Performance standards for antimicrobial susceptibility testing. $24^{\text {th }}$ Informational supplement M100S25. Wayne, PA, USA.

9. Costa D, Poeta P, Saenz Y, et al. (2006): Detection of Escherichia coli harbouring extended-spectrum betalactamases of the CTX-M, TEM and SHV classes in faecal samples of wild animals in Portugal. J Antimicrob Chemother, 58, 1311-1312.

10. Escobar-Páramo P, Le Menac'h A, Le Gall T, et al. (2006): Identification of forces shaping the commensal Escherichia coli genetic structure by comparing animal and human isolates. Environ Microbiol, 8, 1975-1984.

11. Frere JM (1995): Beta-lactamases and bacterial resistance to antibiotics. Mol Microbiol, 16, 385-395.

12. Gonullu N, Aktas Z, Kayacan CB, et al. (2008): Dissemination of CTX-M-15 beta-lactamase genes carried on Inc FI and FII plasmids among clinical isolates of Escherichia coli in a University hospital in Istanbul, Turkey. J Clin Microbiol, 46, 1110-1112.

13. Heffernan HM, Woodhouse RE, Pope CE, et al. (2009): Prevalence and types of extended-spectrum betalactamases among urinary Escherichia coli and Klebsiella spp. in New Zealand. Int J Antimicrob Agents, 34, 544-549.

14. Higgins J, Hohn C, Hornor S, et al. (2007): Genotyping of Escherichia coli from environmental and animal samples. $\mathrm{J}$ Microbiol Methods, 70, 227-235.

15. Jeong SH, Bae IK, Kwon SB, et al. (2005): Dissemination of transferable CTX-M-type extended-spectrum betalactamase-producing Escherichia coli in Korea. J Appl Microbiol, 98, 921-927.

16. Kilani H, Abbassi MS, Ferjani S, et al. (2015): Occurrence of blaCTX-M-1, qnrB1 and virulence genes in avian ESBL-producing Escherichia coli isolates from Tunisia. Front Cell Infect Microbiol, 5, 38.

17. Li L, Jiang ZG, Xia LN, et al. (2010): Characterization of antimicrobial resistance and molecular determinants of beta-lactamase in Escherichia coli isolated from chickens in China during 1970-2007. Vet Microbiol, 144, 505-510.

18. Livermore DM (2012): Current epidemiology and growing resistance of gram-negative pathogens. Korean $\mathrm{J}$ Intern Med, 27, 128-142.
19. Pitout JD, Laupland KB (2008): Extended-spectrum betalactamase-producing Enterobacteriaceae: an emerging public-health concern. Lancet Infect Dis, 8, 159-166.

20. Rossolini GM, D'Andrea MM, Mugnaioli C (2008): The spread of CTX-M-type extended-spectrum beta-lactamases. Clin Microbiol Infect, 14 (Suppl. 1), 33-41.

21. Saladin M, Cao VT, Lambert T, et al. (2002): Diversity of CTX-M beta-lactamases and their promoter regions from Enterobacteriaceae isolated in three Parisian hospitals. FEMS Microbiol Lett, 209, 161-168.

22. Tenover FC, Rasheed JK (2004): Detection of antimicrobial resistance genes and mutations associated with antimicrobial resistance in microorganisms. 391-406. In: DH Persing, FC Tenover, J Versalovic, et al. (Ed), Molecular Microbiology: Diagnostic Principles and Practice. ASM Publishing, Washington DC, USA.

23. Ünal N, Dilik Z, Aşkar Ş, et al. (2014): Prevalence of extended-spectrum beta-lactamase (ESBL) producing Escherichia coli isolates in fecal samples of broilers. Proceedings of the $11^{\text {th }}$ National Congress of Veterinary Microbiology. Antalya, Turkey.

24. Wang G, Clark CG, Rodgers FG (2002): Detection in Escherichia coli of the genes encoding the major virulence factors, the genes defining the O157:H7 serotype, and components of the type 2 shiga toxin family by multiplex PCR. J Clin Microbiol, 40, 3613-3619.

25. Wasyl D, Hasman H, Cavaco LM, et al. (2012): Prevalence and characterization of cephalosporin resistance in nonpathogenic Escherichia coli from food-producing animals slaughtered in Poland. Microb Drug Resist, 18, 79-82.

26. Winn W, Allen S, Janda W, et al. (2006): Koneman's Color Atlas and Textbook of Diagnostic Microbiology. 6th ed. Lippincott Williams and Wilkins, Philadelphia, PA, USA.

Geliş tarihi: 22.08.2016 / Kabul tarihi: 30.11.2016
Address for correspondonce:
Yrd. Doç.Dr. Faruk PEHLIVANOĞLU
Mehmet Akif Ersoy University,
Faculty of Veterinary Medicine,
Department of Microbiology, 15030, Burdur,Turkey.
e-mail:pehlivanoglu@mehmetakif.edu.tr 